\title{
Imposex, female sterility and organotin contamination of the prosobranch Nassarius reticulatus from the Portuguese coast
}

\author{
C. M. Barroso ${ }^{1, *}$, M. H. Moreira ${ }^{1}$, M. J. Bebianno ${ }^{2}$ \\ ${ }^{1}$ Departamento de Biologia, Universidade de Aveiro, 3810 Aveiro, Portugal \\ ${ }^{2}$ Faculdade de Ciências do Mar e do Ambiente, Universidade do Algarve, 8000 Faro, Portugal
}

\begin{abstract}
Samples of Nassarius reticulatus (L.) were obtained from May to July 2000 on the W Portuguese coast. $N$. reticulatus imposex (superimposition of male characters onto female prosobranchs) increased with the proximity of harbours. The percentage of imposex-affected females (\%I) varied between 0 and $100 \%$. The penis length index (PLI) and the relative penis length index (RPLI) were between 0 and $10.7 \mathrm{~mm}$ and 0.0 and $92.1 \%$, respectively. The vas deferens sequence index (VDSI) ranged from 0 to 5 . The average oviduct stage (AOS) varied between 0.0 and 1.3. Sterile females (22 specimens) were found at 8 of the 40 sampling stations with frequencies between 5 and $50 \%$ of the total females sampled at each site. Sterility occurred only in females highly affected with imposex. Tributyltin (TBT) and triphenyltin (TPT) female body burden varied from $<20$ to 1368 and from $<10$ to $256 \mathrm{ng} \mathrm{Sn}^{-1}$ dry weight (dry wt), respectively. The TPT residue was, on average, $18 \%$ of the TBT residue, and there was a highly significant correlation between TBT and $\ln T P T(r=0.88, p<$ 0.001). Dibutyltin (DBT) and monobutyltin (MBT) female body burden varied from $<34$ to 721 and from $<24$ to $703 \mathrm{ng} \mathrm{Sn} \mathrm{g}^{-1}$ dry wt, respectively. TBT represented the major fraction (34 to $60 \%$ ) of the total butyltins, followed by DBT (24 to $40 \%$ ) and MBT (10 to $31 \%$ ). Highly significant correlations ( $\mathrm{p}<$ $0.001)$ were established between the $\ln T B T$ female residue and the indices RPLI $(r=0.88), \operatorname{VDSI}_{(5)}(\mathrm{r}=$ $0.81)$ and AOS $(r=0.72)$, as well as between TBT and percentage female sterility $(\% \mathrm{STER})(\mathrm{r}=0.61)$.
\end{abstract}

KEY WORDS: Nassarius reticulatus · Imposex $\cdot$ Portugal $\cdot$ Tributyltin $\cdot$ Triphenyltin $\cdot$ Sterility Resale or republication not permitted without written consent of the publisher

\section{INTRODUCTION}

Ships' antifouling paints containing triorganotin compounds - tributyltin (TBT) and, to a lesser extent, triphenyltin (TPT) - were introduced in the 1960s (Bennett 1996). Imposex, the superimposition of male characters onto female prosobranchs (Smith 1971), has been reported for over 118 species worldwide (Bettin et al. 1996). It is now well established that imposex is caused by organotin pollution. The ecological impact of this phenomenon may be severe since imposex may cause female sterility in some species. This impact is

*E-mail: cmiguez@bio.ua.pt particularly strong in those species that lack a planktonic larval stage, such as Nucella lapillus (L.), which are vulnerable to local extinction (Bryan et al. 1986). Legislation to ban the use of TBT paints on small boats $(<25 \mathrm{~m})$ was introduced in France in 1982, mainly motivated by the negative impact of TBT pollution on oyster farming. Later, similar legislation was applied in most European (EC directive 89/677/EEC) and other countries (Mora 1996, Stewart 1996). Portugal adopted the above EC directive in 1993 and the Portuguese Navy imposed a total ban on their ships in 1992. Although TBT contamination and imposex declined in many coastal areas (Gibbs \& Bryan 1994), the problem is still acute in others where large vessels predominate. In face of that, the International Maritime Organization 


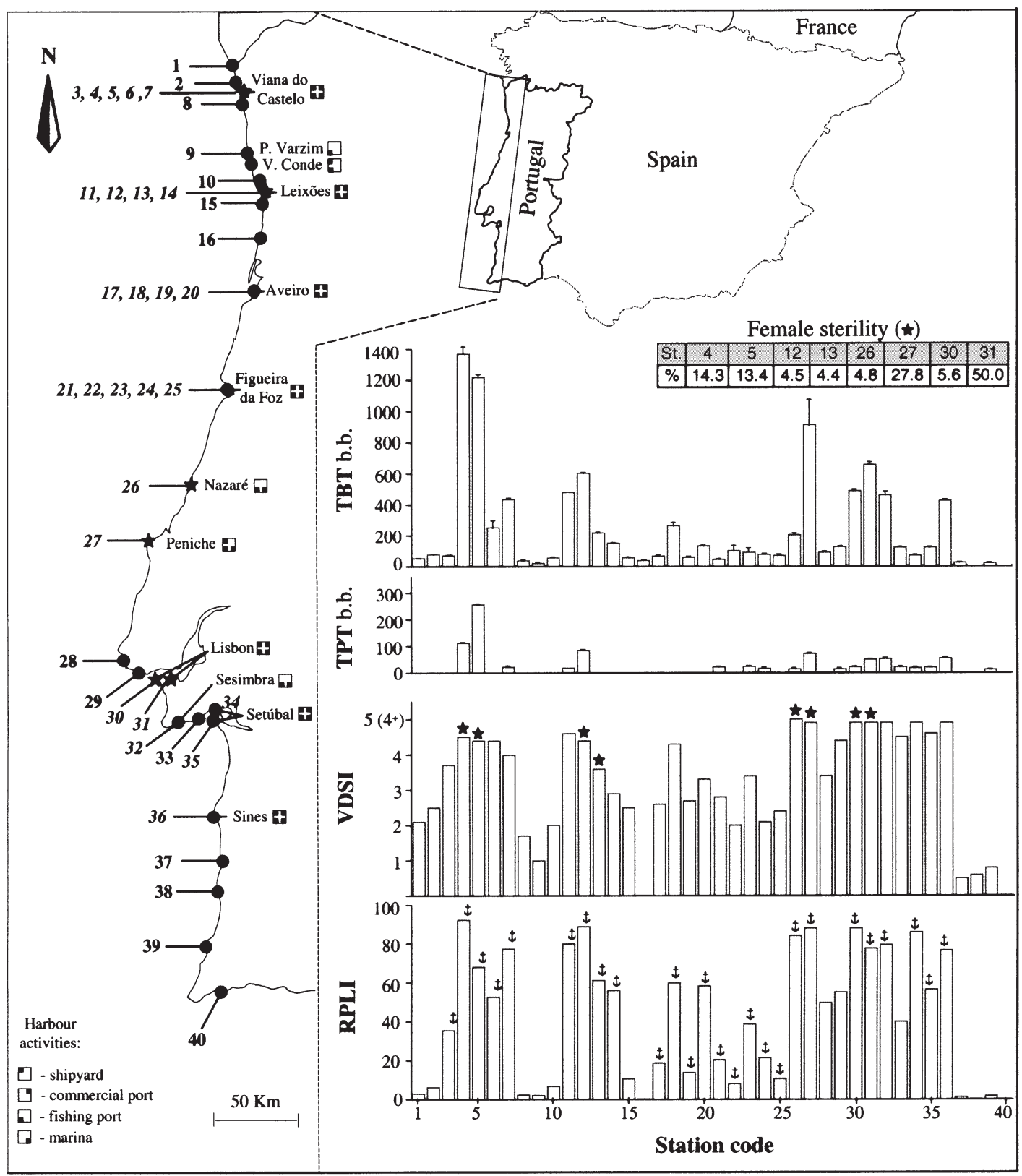

Fig. 1. Nassarius reticulatus. Map of the Portuguese coast indicating the sites (1 to 40) where specimens were collected and the location of the main harbours. Italic code numbers represent sampling stations located inside harbours. The graphic bars represent values of relative penis length index (RPLI), vas deferens sequence index (VDSI), and the mean tributyltin (TBT) and triphenyltin (TPT) whole female body burden (b.b.) (ng Sn g ${ }^{-1}$ dry weight [dry wt]), for each sampling station. Error bars correspond to $1 \mathrm{SD} . \downarrow$ : sampling stations located inside harbours; $\star$ : occurrence of female sterility. For additional data compare Table 1

(IMO) has recently approved a convention for a global ban on the use of organotin antifouling paints by 1 January 2003, considering 1 January 2008 to be the last date for having these paints on a vessel (Champ 2000).

The response of prosobranchs to TPT pollution is poorly understood. This compound was found to induce imposex in Thais clavigera (Küster) (Horiguchi et al. 1997) but not in Nucella lapillus (L.) (Bryan et al.
1988). TPT derivatives are used in agrochemical applications (Bennett 1996, Mensink et al. 1996) and are still added in low proportions to some antifouling paints (Stäb et al. 1995, 1996). Japan prohibited the domestic market of TPT products in 1989 (Horiguchi et al. 1994). However, there is still a low world concern about the use of this compound, mainly due to the scarce knowledge of its biological effects. 
Nassarius reticulatus is a ubiquitous species along the European coast (Graham 1988) that was proposed as a bioindicator of TBT pollution by Stroben et al. (1992a). The aims of the present work were (1) to evaluate the impact of organotin pollution on the populations of $N$. reticulatus on the coast of Portugal; (2) to survey the occurrence of female sterility in this area; and (3) to provide additional validation of the use of this species as a TBT bioindicator at the southern range of its distribution.

\section{STUDY AREA}

The surveyed area was the Portuguese coast between Vila Praia de Âncora (northern limit) and Praia da Luz (southern limit) (Fig. 1, Table 1), where the main Portuguese harbours are situated. These harbours are generally located inside natural embayments, such as estuarine systems, and may include commercial and fishing ports, marinas and shipyard facilities (Fig. 1), which in most cases are close to each other. Table 1 summarises relevant information regarding boat traffic and shipyard activity along the W Portuguese coast. Lisbon harbour is the main national commercial port, followed by Leixões, Setúbal, Aveiro, Sines, Figueira da Foz and Viana do Castelo, a rank that has been maintained since 1993. The Portuguese fishing fleet in 1998 was composed, in terms of gross tonnage stood (GTs), of $12.7 \%$ local small boats (<9 m length) ( 9580 boats), $51.0 \%$ offshore boats (many with more than $25 \mathrm{~m}$ length) (1543 boats) and 36.3\% long-distance vessels (>25 m length) (63 vessels) (information given by National Fishery Data Bank [DGPA]). Fishing boat GTs and the total fish download at each harbour (Table 1) provide an estimate of the relative distribution of the fleet in the $\mathrm{W}$ coast. In this part of the Portuguese coast, there are 17 main marinas with an average berthing capacity (YBC) of 260 yachts, and only 2 of them are located outside the above mentioned harbours: Oporto-Douro (250 YBC) and Cascais (638 YBC) (Anonymous 2000b). There are also many small boat landings spread along the coast. The main shipyards in W Portugal are located in the harbours of Viana do Castelo (V. Castelo), Vila do Conde (V. Conde), Aveiro, Figueira da Foz (F. Foz), Peniche, Lisbon and Setúbal (Table 1).

\section{MATERIALS AND METHODS}

Sampling and pre-treatment. Nassarius reticulatus was sampled from May to July 2000. Sampling locations were selected in order to provide an extensive coverage of the $\mathrm{W}$ coast, including the main national harbours (Fig. 1, Table 1). Geographical co-ordinates were determined with a mobile global positioning system (GPS) at each sampling site. The specimens were collected by hand at the intertidal shore and with baited hoop nets at sub-litoral sites. The animals were maintained in aquaria for about 3 to $4 \mathrm{~d}$. About 40 animals were analysed for each station. Only adult animals (i.e. those presenting white columellar callus and teeth on the outer lip) were selected. They were narcotised using $7 \% \mathrm{MgCl}_{2}$ in distilled water. The shell height (distance from shell apex to lip of siphonal canal) was measured with vernier callipers to the nearest $0.1 \mathrm{~mm}$. The shells were cracked open with a bench vice, and the individuals were sexed and dissected under a stereo microscope. Parasitised specimens were discarded from the analysis.

Imposex analysis. The following imposex parameters were determined for each station: mean female penis length index (PLI), relative penis length index $($ RPLI $=$ mean female penis length $\times 100 /$ mean male penis length), vas deferens sequence index (VDSI), average oviduct stage (AOS) and percentage of females affected by imposex (\%I). The penis length was measured using $1 \mathrm{~mm}$ graduated graph paper under a stereo microscope. The VDSI was classified

Table 1. Characterisation of boat traffic and shipyard activity in the Portuguese coast: total number of commercial ships called at each port during 1999 and respective total gross tonnage stood (GTs) (T: tons) (Anonymous 2000a); fishing boat GTs registered in 1999 and average fish download (Fish dow.) in the period 1998 to 1999 (information obtained from the National Fishery Data Bank), as a parameter to estimate the relative importance of fishing boat traffic between harbours; local leisure boat traffic is classified according to the yacht number berthing capacity (YBC) of all marinas at each site (Anonymous 2000b). P: presence of shipyards in the harbours

\begin{tabular}{|lcccccc|}
\hline & \multicolumn{3}{c}{ Commercial shipping } & \multicolumn{2}{c|}{ Fishing boats } & Marina \\
Harbours & No. & $\begin{array}{c}\text { GTs } \\
\left(\times 10^{6} \mathrm{~T}\right)\end{array}$ & $\begin{array}{c}\text { GTs } \\
\left(\times 10^{3} \mathrm{~T}\right)\end{array}$ & $\begin{array}{c}\text { Fish dow. } \\
\left(\times 10^{3} \mathrm{~T}\right)\end{array}$ & YBC & yards \\
\hline V. Castelo & 302 & 1.1 & 8.6 & 2.0 & 300 & $\mathrm{P}$ \\
P. Varzim & - & - & 2.8 & 3.6 & 241 & \\
V. Conde & - & - & 3.3 & - & - & $\mathrm{P}$ \\
Leixões & 3037 & 20.7 & 5.4 & 30.4 & 240 & \\
Aveiro & 1211 & 2.7 & 32.5 & 20.1 & 270 & $\mathrm{P}$ \\
F. Foz & 316 & 0.6 & 2.9 & 16.0 & 233 & $\mathrm{P}$ \\
Nazaré & - & - & 1.1 & 4.6 & 70 & \\
Peniche & - & - & 8.2 & 23.5 & 150 & $\mathrm{P}$ \\
Lisbon & 3597 & 37.8 & 14.2 & 175.5 & 1887 & $\mathrm{P}$ \\
Sesimbra & - & - & 4.4 & 16.8 & 130 & \\
Setúbal & 1706 & 17.3 & 2.2 & 3.5 & 155 & $\mathrm{P}$ \\
Sines & 773 & 13.4 & 0.8 & 10.3 & 230 & \\
\hline
\end{tabular}


Table 2. Data on Nassarius reticulatus collected along the Portuguese coast: mean $(\bar{x})$ shell heights of males $\left(\sigma^{7}\right)$ and females $\left({ }^{\circ}\right)$ $(\mathrm{mm})$, percentage of imposex-affected females (\%I), mean female penis length index (mm) (PLI), average oviduct stage (AOS), vas deferens sequence index (VDSI $)$ and mean dibutyltin (DBT) and monobutyltin (MBT) whole female body burden (b.b.) at each sampling station. Standard deviations are given as a percentage of the mean: (a) 0 to $5 \%$; (b) 5 to $10 \%$; (c) 10 to $15 \%$; (d) 15 to $20 \%$; (e) 20 to $25 \%$; and (f) 25 to $30 \%$. DW: dry weight; nq: not quantifiable; ${ }^{*} 1$ replicate. For additional data compare Fig. 1

\begin{tabular}{|c|c|c|c|c|c|c|c|c|c|c|c|}
\hline Station code and name & $\begin{array}{c}\text { Coordinates } \\
\text { (EUR50) }\end{array}$ & $\begin{array}{c}0^{7} \\
(\mathrm{~N})\end{array}$ & $\begin{array}{c}\text { ơ shell } \\
\text { height } \\
(\bar{x})\end{array}$ & $\begin{array}{c}\stackrel{9}{+} \\
(\stackrel{N}{)})\end{array}$ & $\begin{array}{l}\text { o shell } \\
\text { height } \\
\qquad(\bar{X})\end{array}$ & $\% \mathrm{I}$ & $\begin{array}{l}\text { PLI } \\
(\bar{x})\end{array}$ & AOS & $\operatorname{VDSI}_{(4)}$ & $\begin{array}{r}\text { Tissu } \\
\text { ng Sn } \\
\text { DBT }\end{array}$ & $\begin{array}{l}\text { e b.b. } \\
g^{-1} \mathrm{DW} \\
\mathrm{MBT}\end{array}$ \\
\hline 1. Vila Praia de Âncora & $41^{\circ} 48.93 \mathrm{~N}-8^{\circ} 51.94 \mathrm{~W}$ & 21 & $21.9^{\mathrm{b}}$ & 22 & $22.1^{\mathrm{b}}$ & 91 & 0.4 & 0.0 & 2.1 & $57^{\mathrm{a}}$ & $31^{\mathrm{b}}$ \\
\hline 2. Praia Norte & $41^{\circ} 41.85 \mathrm{~N}-8^{\circ} 51.13 \mathrm{~W}$ & 21 & $21.1^{b}$ & 26 & $22.5^{\mathrm{b}}$ & 100 & 0.8 & 0.0 & 2.5 & $63^{\mathrm{a}}$ & nq \\
\hline 3. V. Castelo - Marégrafo & $41^{\circ} 41.43 \mathrm{~N}-8^{\circ} 49.71 \mathrm{~W}$ & 15 & $22.6^{\mathrm{b}}$ & 22 & $23.8^{\mathrm{c}}$ & 100 & 4.5 & 0.1 & 3.5 & $97^{b}$ & $\mathrm{nq}$ \\
\hline 4. V. Castelo - Estaleiro & $41^{\circ} 41.34 \mathrm{~N}-8^{\circ} 50.26 \mathrm{~W}$ & 15 & $22.9^{\mathrm{b}}$ & 28 & $25.3^{\mathrm{b}}$ & 100 & 11.5 & 1.0 & 3.9 & $654^{\mathrm{a}}$ & $463^{\mathrm{c}}$ \\
\hline 5. V. Castelo - Cais & $41^{\circ} 41.38 \mathrm{~N}-8^{\circ} 50.01 \mathrm{~W}$ & 15 & $22.1^{\mathrm{b}}$ & 15 & $22.9^{b}$ & 100 & 7.7 & 0.5 & 3.6 & $561^{\mathrm{d}}$ & $462^{\mathrm{b}}$ \\
\hline 6. V. Castelo - Marina & $41^{\circ} 41.70 \mathrm{~N}-8^{\circ} 49.20 \mathrm{~W}$ & 15 & $22.0^{\mathrm{b}}$ & 21 & $22.6^{\mathrm{b}}$ & 100 & 6.3 & 0.3 & 3.9 & $155^{\mathrm{f}}$ & $\mathrm{nq}$ \\
\hline 7. V. Castelo - Barra & $41^{\circ} 41.06 \mathrm{~N}-8^{\circ} 50.24 \mathrm{~W}$ & 14 & $23.2^{\mathrm{b}}$ & 26 & $25.9^{\mathrm{b}}$ & 100 & 9.8 & 1.0 & 3.6 & $195^{\mathrm{a}}$ & $101^{\mathrm{c}}$ \\
\hline 8. Praia da Amorosa & $41^{\circ} 38.72 \mathrm{~N}-8^{\circ} 49.31 \mathrm{~W}$ & 17 & $22.3^{\mathrm{b}}$ & 37 & $23.7^{b}$ & 81 & 0.3 & 0.0 & 1.7 & $37^{\mathrm{e}}$ & nq \\
\hline 9. Póvoa do Varzim & $41^{\circ} 23.18 \mathrm{~N}-8^{\circ} 46.40 \mathrm{~W}$ & 17 & $24.2^{\mathrm{b}}$ & 26 & $24.9^{\mathrm{b}}$ & 69 & 0.3 & 0.0 & 1.0 & $\mathrm{nq}$ & $\mathrm{nq}$ \\
\hline 10. Praia de Leça & $41^{\circ} 12.21 \mathrm{~N}-8^{\circ} 42.82 \mathrm{~W}$ & 15 & $23.5^{\mathrm{c}}$ & 26 & $24.4^{\mathrm{b}}$ & 85 & 0.9 & 0.0 & 2.0 & $34^{\mathrm{b}}$ & $24^{\mathrm{a}}$ \\
\hline 11. Porto de Leixões - Plat. 2 & $41^{\circ} 11.42 \mathrm{~N}-8^{\circ} 41.43 \mathrm{~W}$ & 15 & $24.1^{\mathrm{b}}$ & 26 & $24.7^{\mathrm{b}}$ & 100 & 10.4 & 1.2 & 3.9 & $205^{*}$ & $158^{*}$ \\
\hline 12. Porto de Leixões - Marina & $41^{\circ} 11.30 \mathrm{~N}-8^{\circ} 42.24 \mathrm{~W}$ & 20 & $22.5^{\mathrm{b}}$ & 22 & $24.3^{\mathrm{b}}$ & 100 & 10.7 & 0.7 & 3.9 & $354^{\mathrm{a}}$ & $184^{\mathrm{b}}$ \\
\hline 13. Porto de Leixões - Plat. 1 & $41^{\circ} 11.26 \mathrm{~N}-8^{\circ} 41.89 \mathrm{~W}$ & 15 & $26.6^{\mathrm{b}}$ & 23 & $25.9^{\mathrm{b}}$ & 100 & 7.4 & 0.7 & 3.3 & $194^{\mathrm{a}}$ & $103^{b}$ \\
\hline 14. Porto de Leixões - Barra & $41^{\circ} 10.75 \mathrm{~N}-8^{\circ} 41.43 \mathrm{~W}$ & 15 & $23.3^{\mathrm{c}}$ & 24 & $24.3^{\mathrm{b}}$ & 100 & 6.3 & 0.0 & 2.9 & $78^{a}$ & $33^{\mathrm{b}}$ \\
\hline 15. Praia da Foz & $41^{\circ} 09.78 \mathrm{~N}-8^{\circ} 41.10 \mathrm{~W}$ & 15 & $25.0^{\mathrm{b}}$ & 27 & $25.1^{b}$ & 100 & 1.3 & 0.0 & 2.5 & $44^{\mathrm{b}}$ & $31^{\mathrm{d}}$ \\
\hline 16. Espinho & $41^{\circ} 00.44 \mathrm{~N}-8^{\circ} 38.71 \mathrm{~W}$ & 15 & $25.4^{\mathrm{b}}$ & 25 & $26.9^{b}$ & 0 & 0.0 & 0.0 & 0.0 & $\mathrm{nq}$ & $\mathrm{nq}$ \\
\hline 17. Aveiro - S. Jacinto & $40^{\circ} 39.84 \mathrm{~N}-8^{\circ} 43.56 \mathrm{~W}$ & 14 & $21.8^{\mathrm{c}}$ & 17 & $24.0^{\mathrm{c}}$ & 94 & 2.6 & 0.0 & 2.6 & $49^{d}$ & nq \\
\hline 18. Aveiro - Porto Com. Norte & $40^{\circ} 39.06 \mathrm{~N}-8^{\circ} 43.76 \mathrm{~W}$ & 15 & $22.7^{b}$ & 27 & $23.6^{\mathrm{b}}$ & 100 & 7.2 & 0.1 & 3.7 & $131^{\mathrm{c}}$ & $45^{\mathrm{d}}$ \\
\hline 19. Aveiro - Barra & $40^{\circ} 38.71 \mathrm{~N}-8^{\circ} 44.82 \mathrm{~W}$ & 15 & $23.6^{\mathrm{b}}$ & 27 & $24.3^{\mathrm{b}}$ & 100 & 1.8 & 0.0 & 2.7 & $62^{\mathrm{c}}$ & $\mathrm{nq}$ \\
\hline 20. Aveiro - Magalhães Mira & $40^{\circ} 38.65 \mathrm{~N}-8^{\circ} 44.06 \mathrm{~W}$ & 15 & $25.0^{\mathrm{b}}$ & 21 & $25.5^{\mathrm{c}}$ & 100 & 7.0 & 0.0 & 3.2 & $81^{\mathrm{a}}$ & $30^{\mathrm{b}}$ \\
\hline 21. F. Foz - Marina & $40^{\circ} 08.91 \mathrm{~N}-8^{\circ} 51.67 \mathrm{~W}$ & 10 & $25.8^{\mathrm{b}}$ & 17 & $27.1^{\mathrm{a}}$ & 100 & 2.2 & 0.0 & 2.8 & $40^{\mathrm{a}}$ & $\mathrm{nq}$ \\
\hline 22. F. Foz - Barra & $40^{\circ} 08.86 \mathrm{~N}-8^{\circ} 51.90 \mathrm{~W}$ & 15 & $24.5^{\mathrm{b}}$ & 26 & $26.6^{\mathrm{b}}$ & 85 & 1.1 & 0.1 & 2.0 & $37^{\mathrm{c}}$ & nq \\
\hline 23. F. Foz - Estaleiro & $40^{\circ} 08.60 \mathrm{~N}-8^{\circ} 51.55 \mathrm{~W}$ & 14 & $23.7^{b}$ & 15 & $24.8^{\mathrm{b}}$ & 100 & 5.5 & 0.1 & 3.4 & $55^{\mathrm{e}}$ & $44^{\mathrm{c}}$ \\
\hline 24. F. Foz - Porto de Pesca & $40^{\circ} 08.52 \mathrm{~N}-8^{\circ} 51.43 \mathrm{~W}$ & 14 & $28.7^{\mathrm{b}}$ & 15 & $28.4^{\mathrm{b}}$ & 87 & 3.0 & 0.0 & 2.1 & $59^{\mathrm{a}}$ & $\mathrm{nq}$ \\
\hline 25. F. Foz - Cais Comercial & $40^{\circ} 08.90 \mathrm{~N}-8^{\circ} 51.60 \mathrm{~W}$ & 15 & $25.4^{\mathrm{b}}$ & 15 & $25.7^{\mathrm{b}}$ & 100 & 1.4 & 0.0 & 2.4 & $\mathrm{nq}$ & $49^{\mathrm{a}}$ \\
\hline 26. Nazaré - Porto de Pesca & $39^{\circ} 35.04 \mathrm{~N}-9^{\circ} 04.39 \mathrm{~W}$ & 18 & $22.6^{\mathrm{b}}$ & 21 & $22.5^{\mathrm{b}}$ & 100 & 8.7 & 1.1 & 4.0 & $177^{\mathrm{a}}$ & $116^{\mathrm{b}}$ \\
\hline 27. Peniche - Porto de Pesca & $39^{\circ} 21.15 \mathrm{~N}-9^{\circ} 22.52 \mathrm{~W}$ & 19 & $19.2^{\mathrm{d}}$ & 18 & $19.4^{\mathrm{b}}$ & 100 & 8.5 & 0.3 & 4.0 & $671^{\mathrm{a}}$ & $703^{\mathrm{b}}$ \\
\hline 28. Praia do Guincho & $38^{\circ} 43.74 \mathrm{~N}-9^{\circ} 28.46 \mathrm{~W}$ & 22 & $22.6^{\mathrm{b}}$ & 25 & $23.0^{\mathrm{c}}$ & 100 & 7.3 & 0.3 & 3.3 & $103^{a}$ & $62^{\mathrm{e}}$ \\
\hline 29. Praia das Avencas & $38^{\circ} 41.21 \mathrm{~N}-9^{\circ} 21.27 \mathrm{~W}$ & 15 & $24.1^{\mathrm{b}}$ & 28 & $24.4^{\mathrm{b}}$ & 100 & 7.6 & 0.1 & 4.0 & $121^{\mathrm{a}}$ & $74^{\mathrm{a}}$ \\
\hline 30. Lisboa - Trafaria & $38^{\circ} 40.55 \mathrm{~N}-9^{\circ} 14.09 \mathrm{~W}$ & 20 & $23.3^{\mathrm{b}}$ & 18 & $22.1^{\mathrm{c}}$ & 100 & 7.7 & 1.3 & 4.0 & $275^{\mathrm{a}}$ & $145^{\mathrm{c}}$ \\
\hline 31. Lisboa - Porto Brandão & $38^{\circ} 40.77 \mathrm{~N}-9^{\circ} 12.29 \mathrm{~W}$ & 17 & $20.2^{\mathrm{b}}$ & 14 & $19.8^{\mathrm{c}}$ & 100 & 9.0 & 0.8 & 4.0 & $721^{\mathrm{a}}$ & $558^{\mathrm{a}}$ \\
\hline 32. Sesimbra - Porto de Pesca & $38^{\circ} 26.25 \mathrm{~N}-9^{\circ} 06.76 \mathrm{~W}$ & 15 & $23.5^{\mathrm{b}}$ & 26 & $23.7^{b}$ & 100 & 10.1 & 0.8 & 4.0 & $413^{\mathrm{a}}$ & $327^{\mathrm{c}}$ \\
\hline 33. Portinho da Arrábida & $38^{\circ} 28.58 \mathrm{~N}-8^{\circ} 58.97 \mathrm{~W}$ & 16 & $22.4^{\mathrm{b}}$ & 20 & $22.9^{b}$ & 100 & 4.3 & 0.0 & 3.8 & $79^{\mathrm{a}}$ & $49^{\mathrm{a}}$ \\
\hline 34. Setúbal - Porto de Pesca & $38^{\circ} 31.17 \mathrm{~N}-8^{\circ} 52.58 \mathrm{~W}$ & 25 & $21.1^{\mathrm{b}}$ & 20 & $22.1^{\mathrm{c}}$ & 100 & 7.9 & 0.8 & 4.0 & $63^{\mathrm{b}}$ & $36^{\mathrm{a}}$ \\
\hline 35. Setúbal - Tróia & $38^{\circ} 26.25 \mathrm{~N}-9^{\circ} 06.76 \mathrm{~W}$ & 15 & $21.3^{\mathrm{b}}$ & 23 & $21.7^{\mathrm{b}}$ & 100 & 5.9 & 0.3 & 4.0 & $90^{\mathrm{a}}$ & $48^{\mathrm{b}}$ \\
\hline 36. Sines - Porto de Pesca & $37^{\circ} 57.28 \mathrm{~N}-8^{\circ} 52.21 \mathrm{~W}$ & 16 & $22.1^{\mathrm{b}}$ & 24 & $22.1^{b}$ & 100 & 8.7 & 0.9 & 4.0 & $239^{a}$ & $108^{a}$ \\
\hline 37. Vila Nova de Mil Fontes & $37^{\circ} 43.30 \mathrm{~N}-8^{\circ} 47.25 \mathrm{~W}$ & 16 & $23.1^{\mathrm{b}}$ & 27 & $23.4^{\mathrm{b}}$ & 26 & 0.1 & 0.0 & 0.5 & $\mathrm{nq}$ & $\mathrm{nq}$ \\
\hline 38. Zambujeira do Mar & $37^{\circ} 33.20 \mathrm{~N}-8^{\circ} 47.44 \mathrm{~W}$ & 15 & $22.6^{\mathrm{b}}$ & 20 & $23.7^{b}$ & 58 & 0.01 & 0.0 & 0.6 & nq & $\mathrm{nq}$ \\
\hline 39. Praia da Arrifana & $37^{\circ} 17.82 \mathrm{~N}-8^{\circ} 52.11 \mathrm{~W}$ & 15 & $20.1^{\mathrm{d}}$ & 20 & $20.4^{\mathrm{b}}$ & 44 & 0.2 & 0.0 & 0.8 & $\mathrm{nq}$ & nq \\
\hline 40. Praia da Luz & $37^{\circ} 05.21 \mathrm{~N}-8^{\circ} 43.64 \mathrm{~W}$ & 15 & $19.8^{\mathrm{a}}$ & 32 & $20.8^{\mathrm{b}}$ & 0 & 0.0 & 0.0 & 0.0 & nq & nq \\
\hline
\end{tabular}

according to the scoring system proposed by Stroben et al. (1992a). The degree of oviduct convolution, assessed by AOS, was ranked according to the 3-stage scale of Barreiro et al. (2001). The percentage of sterile females (\%STER) per sample was also determined.

Organotin analysis. TBT, dibutyltin (DBT), monobutyltin (MBT) and TPT were measured in the whole tissues of pooled females for each station. The analysis was performed by the Servicios Xerais de Apoio á
Investigación (Universidade da Coruña). The procedures used are described by Quintela et al. (2000) and are largely based on the methods of Szpunar et al. (1996). The analysis was performed for 2 separate replicates of each sample, and the results are given as mean values with the respective standard deviation. The detection limit of the method was $20 \mathrm{ng} \mathrm{Sn} \mathrm{g}^{-1}$ dry weight (dry wt) for butyltins (BT) and $10 \mathrm{ng} \mathrm{Sn}^{-1}$ dry wt for TPT. 


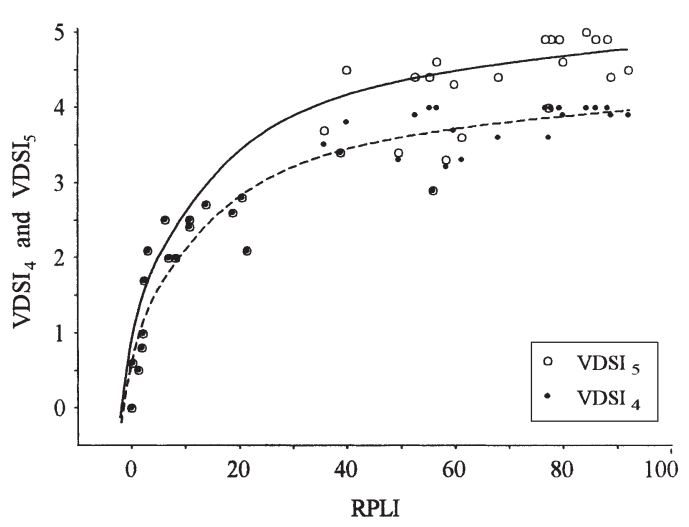

Fig. 2. Nassarius reticulatus. Relationship between RPLI and VDSI, which may be computed converting VDS stage $4^{+}$to either $4\left(\mathrm{VDSI}_{(4)}\right)$ or $5\left(\mathrm{VDSI}_{(5)}\right)$. Lines fitted by eye

\section{RESULTS}

\section{Imposex indices}

The imposex levels of Nassarius reticulatus at the different stations are summarised in Fig. 1 and Table 2. $\%$ I varied between 0 and 100. PLI and RPLI varied, respectively, between 0 and $10.7 \mathrm{~mm}$ and 0.0 and $92.1 \%$ (the mean male penis length was $12.1 \mathrm{~mm}$ ). VDSI ranged from 0 to the maximum possible value of 5 (computing VDS stage $4^{+}$as 5 ; see below). The VDS classification system developed by Stroben et al. (1992a), with stages 0 to $4^{+}$, provided a satisfactory description of the imposex in the observed females. Nevertheless, some differences were found: in $85.7 \%$ of the females showing stage 4 the vas deferens did not join the vulva, whereas in $33.9 \%$ of the females presenting stage $4^{+}$the vas deferens ran parallel to the capsule gland instead of joining this gland. Most females $(97.6 \%)$ presented a-type VDS stages, i.e. with simultaneous penis development (Stroben et al. 1992a). The b-type females occurred at Stns 1, 8, 9, 24 and 38, where VDSI was low (0.8 to 2.3). Regarding the computation of VDSI, Stroben et al. (1992a) proposed the use of the same numerical value of 4 to represent both VDS stages 4 and $4^{+}$(here designated as $\operatorname{VDSI}_{(4)}$ ). However, when stage $4^{+}$is computed with a numerical value of $5\left(\mathrm{VDSI}_{(5)}\right)$ the correlation between VDSI and RPLI across samples is improved $\left(\mathrm{r}_{(\mathrm{VDSI}(5))}=0.90\right.$; $\left.\mathrm{r}_{(\operatorname{VDSI}(4))}=0.85\right)$, resulting in an increased power of discrimination between stations (Fig. 2). This aspect was relevant in this study since the total number of females in VDS stage $4^{+}$was more than twice the number of females in stage 4 (Fig. 3). Nevertheless, $\operatorname{VDSI}_{(4)}$ values are given in Table 2 to allow comparisons with other works.

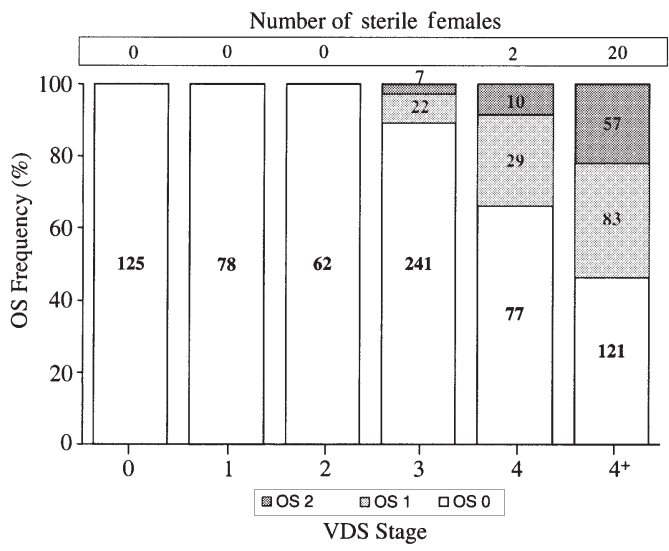

Fig. 3. Nassarius reticulatus. Relative and absolute frequencies of oviduct stages (OS) observed for each VDS stage in females. Number of sterile females presenting each VDS stage

The AOS index varied between 0.0 and 1.3 and was significantly correlated with VDSI across stations ( $\mathrm{r}=$ 0.68 ; $\mathrm{p}<0.001$ ). Oviduct convolution occurred only in females presenting a VDS stage higher than 2. OS stage 1 occurred in 8,25 and $32 \%$ of the females showing VDS stages 3,4 and $4^{+}$, respectively. OS stage 2 was observed in 3, 9 and $22 \%$ of corresponding females. Half of the females that exhibited VDS stage $4^{+}$ had a convoluted oviduct (Fig. 3).

\section{Female sterility}

Females carrying aborted egg capsules inside the capsule gland were found at 8 stations in the ports of Viana do Castelo, Leixões, Nazaré, Peniche and Lisbon. These females were considered to be sterile since they were incapable of laying egg capsules. In total 22 sterile females were found, and their frequencies varied from 5 to $50 \%$ of the females per site (Fig. 1). Sterility occurred only on females that were highly affected with imposex: 20 sterile females showed VDS $4^{+}$and the remaining VDS 4 (Fig. 3).

In the sterile females the aborted egg capsules formed a compact brown mass that, in some cases, gave to the capsule gland a darker and enlarged external appearance, reminiscent of VDS stage 6 of Nucella lapillus (Gibbs \& Bryan 1986), except that there was no external sign of vulva blockage by vas deferens proliferation. Nevertheless, in 5 females the vulva was externally obstructed: in 3 it was covered with a smooth tissue excrescence; in 1 there was a free solid cylindrical excrescence, $4 \mathrm{~mm}$ in length, growing over the vulva; in the other the vulva was very small and appeared to be constricted by the capsule gland wall 


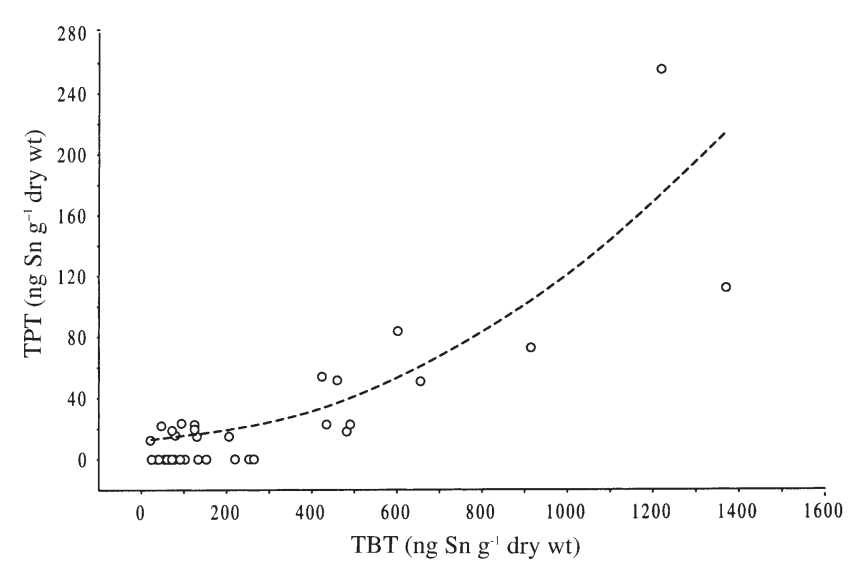

Fig. 4. Nassarius reticulatus. Relationship between TBT and TPT female b.b. across sampling stations. Null values of TPT b.b. represent levels below the analytical detection limit of $10 \mathrm{ng} \mathrm{Sn} \mathrm{g}^{-1}$ dry wt and were excluded from line fitting (by eye)

\section{Organotin tissue contamination}

Nassarius reticulatus organotin body burden at the different stations is summarised in Fig. 1 and Table 2. TBT female body burden varied between $<20$ and 1368 ng Sn g ${ }^{-1}$ dry wt, whereas TPT ranged from $<10$ to $256 \mathrm{ng} \mathrm{Sn} \mathrm{g}^{-1}$ dry wt. There was an evident relationship between triorganotin tissue contamination levels and the proximity of harbours enclosing ports, marinas or shipyards. Among the 13 stations located outside harbours, the TBT body burden did not exceed $128 \mathrm{ng}$ Sn $\mathrm{g}^{-1}$ dry wt, and the TPT was only detected in 2 stations with values not higher than $15 \mathrm{ng} \mathrm{Sn} \mathrm{g}^{-1}$ dry wt.
Where both compounds were quantifiable, the TPT residue was, on average, $18 \%$ of the TBT residue. The TPT concentration increased exponentially with that of TBT (Fig. 4), and a highly significant correlation was established between TBT and $\operatorname{lnTPT}(\mathrm{r}=0.88, \mathrm{p}<$ 0.001). DBT and MBT female body burden varied from

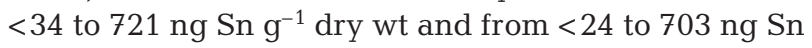
$\mathrm{g}^{-1}$ dry $\mathrm{wt}$, respectively. At the stations where all BT were quantifiable, TBT represented the major fraction (34 to $60 \%$ ) of the total BT, followed by DBT (24 to $40 \%$ ) and MBT (10 to $31 \%$ ).

\section{RPLI, VDSI, AOS and \%STER versus TBT contamination}

Highly significant correlations $(p<0.001)$ were established between $\operatorname{lnTBT}$ and the indices RPLI ( $\mathrm{r}=$ $0.88), \operatorname{VDSI}_{(5)}(\mathrm{r}=0.81)$ and AOS $(\mathrm{r}=0.72)$, as well as between TBT and \%STER ( $\mathrm{r}=0.61)$. Clear relationship patterns were found between the intensity of imposex and the level of TBT tissue concentration across stations (Figs. $5 \& 6$ ). The RPLI and $\operatorname{VDSI}_{(5)}$ rose rapidly up to values around 60 to $80 \%$ and 4.3 to 4.5 , respectively, for TBT tissue concentrations of about $200 \mathrm{ng} \mathrm{Sn} \mathrm{g}^{-1}$ dry wt. Then both indices tended to a plateau of approximately $85 \%$ for RPLI and 4.6 for $\operatorname{VDSI}_{(5)}$, at 700 and $400 \mathrm{ng}$ TBT-Sn g ${ }^{-1}$ dry wt, respectively (Figs. 5 \& $6)$. The AOS index showed a similar trend, reaching a plateau of about 1.0 at a TBT tissue concentration of 400 ng Sn g $^{-1}$ dry wt (Fig. 6). Female sterility was only observed at stations where TBT body burden exceeded 200 ng Sn ${ }^{-1}$ dry wt (Fig. 5).

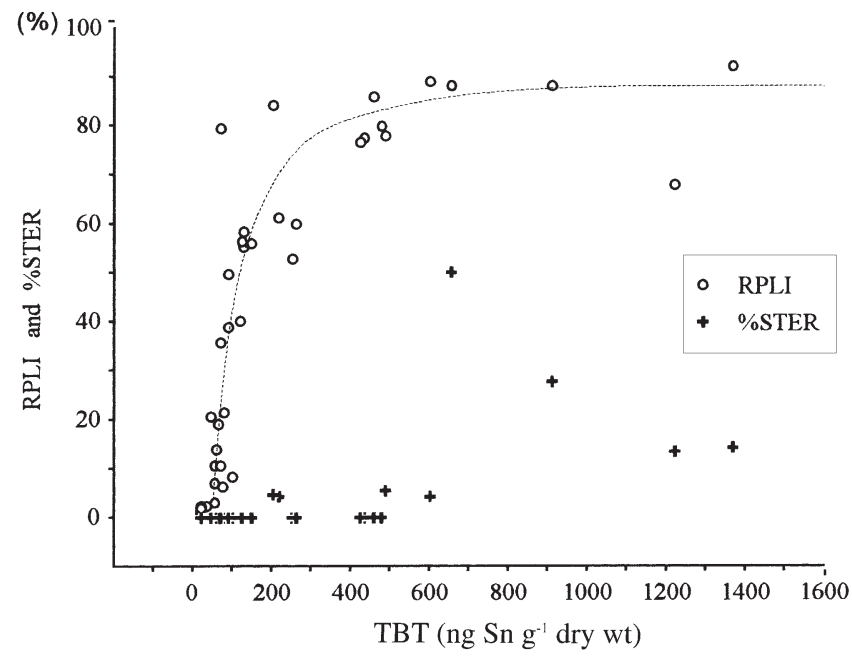

Fig. 5. Nassarius reticulatus. Relationship between the female TBT b.b. and the RPLI and percentage of female sterility (\%STER). Line fitted by eye

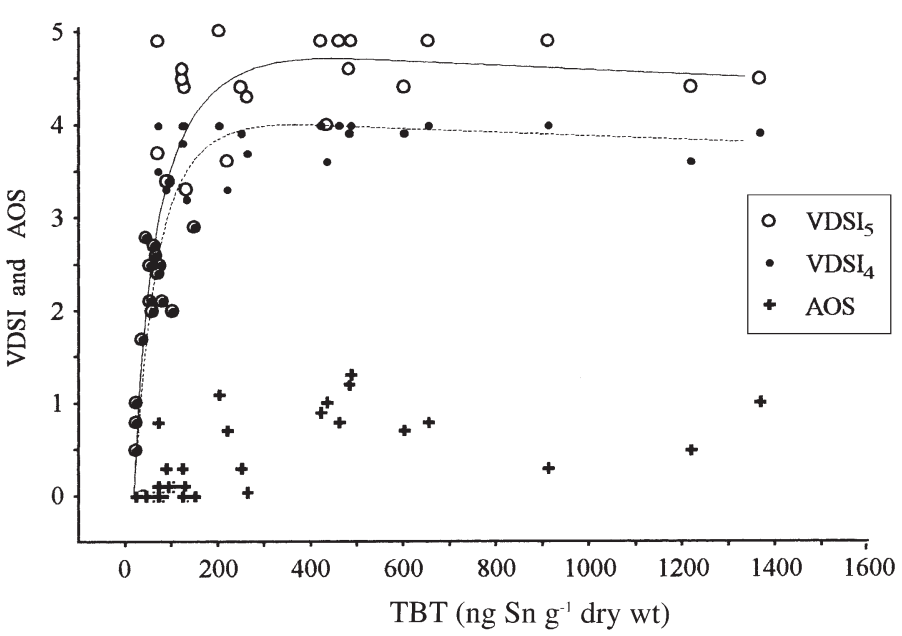

Fig. 6. Nassarius reticulatus. Relationship between the TBT female b.b. and the VDSI and average oviduct stage (AOS) index. Lines fitted by eye 


\section{DISCUSSION}

\section{Biomonitoring organotin pollution}

Nassarius reticulatus occurs along the entire Portuguese mainland coast. In the present survey, it was commonly found at sandy sheltered places of rocky intertidal areas along the seashore, but it was particularly abundant in sandy or muddy sediments inside estuarine systems, where it may withstand a reduction of salinity to about 16 psu (Fretter \& Graham 1985). Nevertheless, the species was very scarce or absent from extremely exposed shores and from several visited sites, namely along the margins of the Tagus (Lisbon) and the Sado (Setúbal) estuaries. Yet the distribution of the species provided a fairly good monitoring coverage of the coast, including the harbours located inside estuarine systems (Viana do Castelo, Aveiro, Figueira da Foz, Lisbon and Setúbal).

Nassarius reticulatus imposex levels were highly correlated with TBT tissue concentrations. RPLI and VDSI depicted the gradient profiles of organotin pollution in the coast around the harbours (Fig. 1). For instance, at Viana do Castelo, the large range of RPLI and $\operatorname{VDSI}_{(5)}$ values observed at Stns 2 to 8 clearly show an increasing TBT gradient from the adjacent coast to the harbour. Identical patterns can be observed at Stns 10 to 15 (around Leixões) and at Stns 28 to 31 (around Lisbon) (Fig. 1). At Aveiro (Stns 17 to 20) and Figueira da Foz (Stns 21 to 25) increasing gradients are also well marked from the mouths towards the organotin sources inside the estuarine systems (Fig. 1).

The $\operatorname{VDSI}_{(5)}$ renders a better assessment of imposex intensity and a better power of discrimination between highly contaminated stations than $\mathrm{VDSI}_{(4)}$. This is to be expected since the transition from VDS stage 4 to $4^{+}$ corresponds to a substantial development of the vas deferens and penis. The adoption of $\mathrm{VDSI}_{(5)}$ would also allow for a more gradual transition to a possible VDS stage 6, corresponding to the abortion of egg capsules. Even so, the discrimination between severely contaminated sites always remains difficult since both VDSI and RPLI reach a plateau for high TBT body burdens (in our study $>400$ and $>700 \mathrm{ng} \mathrm{Sn} \mathrm{g}^{-1}$ dry wt, respectively) (Figs. 5 \& 6). A similar trend was also observed by other authors (Bryan et al. 1993, Barreiro et al. 2001). In view of that, Barreiro et al. (2001) proposed the use of the AOS index for discerning among highly polluted sites, as they found increasing values of AOS for a range of TBT residues where RPLI and VDSI had already reached a plateau. In the present study, although AOS was highly correlated to organotin contamination, it did not offer advantages in this respect.

Nassarius reticulatus can be recommended as a key species for organotin biological effects monitoring in the maritime area covered by the OSPAR Convention for the Protection of the Marine Environment of the North-East Atlantic. In fact, this is a common species in this area that may depict organotin gradients along the coastline in relation to the proximity of harbours, even when they are located inside estuaries. Moreover, this is a moderately sensitive species, when compared to the highly sensitive Nucella lapillus or to the poorly sensitive Littorina littorea (L.), and may therefore provide a better description of organotin gradients around harbours, as was shown at Aveiro by Barroso et al. (2000). On the other hand, the nassariid may be present in hotspots of organotin contamination where $N$. lapillus may already be extinct.

\section{Imposex versus TBT contamination}

The present study and other published works provide useful information regarding the imposex-TBT body burden relationship in Nassarius reticulatus for the NE Atlantic coast, between SW England and SW Portugal, which represents a considerable portion of the OSPAR maritime coastal area. Bryan et al. (1993) published data for SW England between 1985 and 1993 and found differences in the imposex-TBT body burden relationships between pre- and post-TBT ban periods. In either case, there was a sharp increase in RPLI up to $70 \%$ (referred to non-narcotised animals) for TBT residues less than 200 ng Sn $\mathrm{g}^{-1}$ dry wt, as observed in the present study. For specimens collected in NW Spain during 1998 to 1999 the RPLI reached a plateau of about $90 \%$ at $700 \mathrm{ng}$ TBT$\mathrm{Sn}^{-1}$ dry wt, resembling the trend described here for Portugal, although the increase of RPLI at less contaminated levels was less pronounced in NW Spain (Barreiro et al. 2001). However, the relationship described by Stroben et al. (1992a) for the coasts of Brittany and Normandy in 1988 to 1991 is considerably different from that obtained in the present study. For example, females with 200 ng TBT-Sn g $^{-1}$ dry wt exhibited about maximum $\operatorname{VDSI}_{(4)}$ and RPLI $=70 \%$ in Portugal but only about $\operatorname{VDSI}_{(4)}=2$ and RPLI $=3 \%$ in Brittany and Normandy, despite the fact that the mean male penis length was about the same in the 2 regions (12 to $13 \mathrm{~mm}$ ). Although this may partly be attributed to different analytical techniques used - since unspecific methods may overestimate TBT concentrations when other triorganotin residues (such as TPT) are abundantly present - other hypothesis may help to explain the observed discrepancies. One relates to the fact that TBT body burden indicates a short-term bioaccumulation, whilst imposex, being irreversible, is a long-term indicator of the presence of organotin compounds (Bryan et al. 1993). This latter aspect is important considering the life span of the species, which may reach more than $10 \mathrm{yr}$ (Tallmark 
1980, Bryan et al. 1993, C.M.B. unpubl.). Nevertheless, and despite the fact that restrictions on the use of TBT paints were introduced at different dates in Europe (1982 in France; 1987 in England; 1990 in Spain; 1993 in Portugal), the above imposex-TBT body burden relationships were established after similar periods following the TBT ban in each country. Another hypothesis could be related to geographical variability of the species response to organotin.

\section{TBT versus TPT contamination}

In the present survey, TPT was $<10 \mathrm{ng} \mathrm{Sn} \mathrm{g}^{-1}$ dry wt in about half of the sampled stations, whereas TBT in the same places ranged from 22 to $262 \mathrm{ng} \mathrm{Sn} \mathrm{g}^{-1}$ dry wt with a mean value of $97 \mathrm{ng} \mathrm{Sn} \mathrm{g}^{-1}$ dry wt. In the remaining stations, TPT varied between 4 and $62 \%$ (average 18\%) of the TBT residue. As for its sources, TPT is a widely used fungicide in agriculture (potato, rice, sugar beet and celery cropping) and is applied in antifouling paints as a small percentage (approximately $8 \%$ ) together with TBT (Stäb et al. 1996). Considering the high correlation between the 2 organotins in the tissues of Nassarius reticulatus in Portugal, TPT pollution presumably originated from its use in antifouling paints. According to Barreiro et al. (2001), in NW Spain the body burden fraction of TPT in this species is lower (maximum of $14.4 \%$ of TBT), and it is not correlated with that of TBT. Nevertheless, in NW Spain the TPT residue fraction is higher in the vicinity of marinas than it is close to commercial ports. Tolosa et al. (1996) also reported higher concentrations of TPT in the sub-surface waters close to marinas at the Côte d'Azur. In Portugal TPT body burden was not particularly high near the marinas at Stns 6, 12 and 21 (Fig. 1). Comparing N. reticulatus with other species, Ruiz et al. (1998) reported similar low fractions of TPT (about 10 to $50 \%$ of TBT) in the tissues of Nucella lapillus from NW Spain, but this contrasts with Buccinum undatum (L.) from Eastern Scheldt (The Netherlands) (Mensink et al. 1996) as well as with Thais clavigera (Küster) and T. bronni (Dunker) from Japan (Horiguchi et al. 1994), which presented higher levels of TPT than of TBT residues.

\section{Impact of organotin pollution}

The imposex levels of Nassarius reticulatus in the Portuguese harbours are comparable to those reported for the major contaminated harbours of NW Spain (e.g. Coruña, Ferrol and Vigo) (Barreiro et al. 2001) and France (e.g. Roscoff harbour) (Oehlmann et al. 1993), and for the most contaminated sites in SW England before TBT restrictions (e.g. Dart Estuary and Ply- mouth Sound) (Bryan et al. 1993). The development of the female penis and sperm duct (vas deferens) has been consistently correlated with organotin pollution in this and other field studies (Stroben et al. 1992a,b, Bryan et al. 1993, Oehlmann et al. 1993, Huet et al. 1995, Barroso et al. 2000, Barreiro et al. 2001), and it has also been shown, under laboratory conditions, that these male characters are induced by exposure to TBT (Stroben et al. 1992b, Bettin et al. 1996). N. reticulatus females from Portugal also presented some degree of oviduct convolution. This was previously described by Stroben et al. (1992a) in France, although only afflicting $2 \%$ of the analysed females, and by Barreiro et al. (2001) in NW Spain, to an extent comparable to that found in the present study. Smith (1980) reported the same phenomenon for Ilyanassa (= Nassarius) obsoleta (Say) and considered that it was a sign of masculinisation because it resembles the sinuous seminal vesicle of the males. This syndrome was highly correlated with organotin body burden in the present survey and in NW Spain (Barreiro et al. 2001), but there is still the need to establish a causal relationship using experimental designs. The present work also reveals that female sterility is highly correlated with organotin contamination but, again, there is no experimental support showing that sterility results from organotin exposure. The first report on $N$. reticulatus sterility came from the west of France (Huet et al. 1995), where 2 sterile females with aborted egg capsules were found at a highly TBT polluted site. Recently, Barreiro et al. (2001) found 40 sterile females, also with aborted egg capsules, at highly polluted places in NW Spain, affecting up to $26 \%$ females per station. In the present survey, 22 similar sterile females were found at the most polluted sites of Portugal (Fig. 1), afflicting up to $50 \%$ of the females per station. Hence, sterilisation of $N$. reticulatus females appears to be a broad phenomenon consistently associated with high organotin pollution levels and maximum VDS scores $\left(4^{+}\right)$(Fig. 3), which deserves further investigation.

The present work has shown that organotin pollution remains a cause for concern on the Portuguese coast, especially in the estuarine systems where most harbours are located. This may indicate that the implementation in 1993 of restrictions on the use of TBT antifouling paints was not effective and that vessels larger than $25 \mathrm{~m}$ and shipyards probably still are the main sources of organotin contamination, which reinforces the need for further restrictions.

Acknowledgements. This work was partly supported by the Portuguese Ministry of National Defence and the Foundation of the Portuguese Universities. The authors wish to thank Sr Rui Marques and Francisco Maia for their helpful assistance in field work. 


\section{LITERATURE CITED}

Anonymous (2000a) Ports statistics. Ports of Portugal 8 (Ano IV):27-30

Anonymous (2000b) Serviços, marinas e portos. Navegar 22: 62

Barreiro R, González R, Quintela, M, Ruiz JM (2001) Imposex, organotin bioaccumulation and sterile females in Nassarius reticulatus from polluted areas of NW Spain. Mar Ecol Prog Ser 218:203-212

Barroso CM, Moreira MH, Gibbs PE (2000) Comparison of imposex and intersex development in four prosobranch species for TBT monitoring of a Southern Europe estuarine system (Ria de Aveiro, NW Portugal). Mar Ecol Prog Ser 201:221-232

Bennett RF (1996) Industrial manufacture and applications of tributyltin compounds. In: Mora SJ (ed) Tributyltin: case study of an environmental contaminant. Cambridge environmental chemistry series 8. Cambridge University Press, Cambridge, p 21-61

Bettin C, Oehlmann J, Stroben E (1996) TBT-induced imposex in marine neogastropods is mediated by an increasing androgen level. Helgol Wiss Meeresunters 50:299-317

Bryan GW, Gibbs PE, Hummerstone LG, Burt GR (1986) The decline of the gastropod Nucella lapillus around SouthWest England: evidence for the effect of tributyltin from antifouling paints. J Mar Biol Assoc UK 66:611-640

Bryan GW, Gibbs PE, Burt GR (1988) A comparison of the effectiveness of tri-n-butyltin and five other organotin compounds in promoting the development of imposex in the dog-whelk, Nucella lapillus. J Mar Biol Assoc UK 68: 733-744

Bryan GW, Burt GR, Gibbs PE, Pascoe PL (1993) Nassarius reticulatus (Nassariidae: Gastropoda) as an indicator of tributyltin pollution before and after TBT restrictions. J Mar Biol Assoc UK 73:913-929

Champ MA (2000) A review of organotin regulatory strategies: pending actions, related costs and benefits. Sci Total Environ 258:21-71

Fretter V, Graham A (1985) The prosobranch molluscs of Britain and Denmark. Part 8-Neogastropoda. J Mollusc Stud (Suppl) 15:435-556

Gibbs PE, Bryan GW (1986) Reproductive failure in populations of the dog-whelk, Nucella lapillus, caused by imposex induced by tributyltin from antifouling paints. J Mar Biol Assoc UK 66:767-777

Gibbs PE, Bryan GW (1994) Biomonitoring of tributyltin (TBT) pollution using the imposex response of neogastropods molluscs. In: Kramer KJM (ed) Biomonitoring of coastal waters and estuaries. CRC Press, Boca Raton, p 205-226

Graham A (1988) Molluscs: prosobranch and pyramidellid gastropods. Synopses of the British fauna (new series) 2. Brill Academic Publishers, Leiden

Horiguchi T, Shiraishi H, Shimizu M, Morita M (1994) Imposex and organotin compounds in Thais clavigera and $T$. bronni in Japan. J Mar Biol Assoc UK 74:651-669

Horiguchi T, Shiraishi H, Shimizu M, Morita M (1997) Effects of triphenyltin chloride and five other organotin compounds on the development of imposex in the rock shell, Thais clavigera. Environ Pollut 95:85-91

Editorial responsibility: Otto Kinne (Editor), Oldendorf/Luhe, Germany
Huet M, Fioroni P, Oehlmann J, Stroben E (1995) Comparison of imposex response in three prosobranch species. Hydrobiologia 309:29-35

Mensink BP, Hallers-Tjabbes CC, Kralt J, Freriks IL, Boon JP (1996) Assessment of imposex in the common whelk, Buccinum undatum (L.) from the Eastern Scheldt, The Netherlands. Mar Environ Res 41:315-325

Mora J (1996) The tributyltin debate: ocean transportation versus seafood harvesting. In: Mora SJ (ed) Tributyltin: case study of an environmental contaminant. Cambridge environmental chemistry series 8 . Cambridge University Press, Cambridge, p 1-20

Oehlmann J, Stroben E, Fioroni P (1993) Fréquence et degré d'expression du pseudohermaphrodisme chez quelques prosobranches sténoglosses des côtes françaises (surtout de la baie de Morlaix et de la Manche). 2. Situation jusqu'au printemps de 1992. Cah Biol Mar 34:343-362

Quintela M, Barreiro R, Ruiz JM (2000) The use of Nucella lapillus (L.) transplanted in cages to monitor tributyltin (TBT) pollution. Sci Total Environ 247:227-237

Ruiz JM, Quintela M, Barreiro R (1998) Ubiquitous imposex and organotin bioaccumulation in gastropods Nucella lapillus from Galicia (NW Spain): a possible effect of nearshore shipping. Mar Ecol Prog Ser 164:237-244

Smith BS (1971) Sexuality in the American mud snail Nassarius obsoletus Say. Proc Malacol Soc Lond 39:377-378

Smith BS (1980) The estuarine mud snail, Nassarius obsoletus: abnormalities in the reproductive system. J Mollusc Stud 46:247-256

Stäb JA, Frenay M, Freriks IL, Brinkman UT, Cofino WP (1995) Survey of nine organotin compounds in the Netherlands using the zebra mussel (Dreissena polymorpha) as biomonitor. Environ Toxicol Chem 14:2023-2032

Stäb JA, Traas TP, Stroomberg G, van Kesteren J and 4 others (1996) Determination of organotin compounds in the foodwebb of a shallow freshwater lake in the Netherlands. Arch Environ Contam Toxicol 31:319-328

Stewart C (1996) The efficacy of legislation in controlling tributyltin in the marine environment. In: Mora SJ (ed) Tributyltin: case study of an environmental contaminant. Cambridge environmental chemistry series 8. Cambridge University Press, Cambridge, p 264-297

Stroben E, Oehlmann J, Fioroni P (1992a) The morphological expression of imposex in Hinia reticulata (Gastropoda: Buccinidae): a potential indicator of tributyltin pollution. Mar Biol 113:625-636

Stroben E, Oehlmann J, Fioroni P (1992b) Hinia reticulata and Nucella lapillus. Comparison of two gastropod tributyltin bioindicators. Mar Biol 114:289-296

Szpunar J, Schmitt VO, Lobinski R (1996) Rapid speciation of butyltin compounds in sediments and biomaterials by CGC-MIP-AES after microwave-assisted leaching/digestion. J Anal At Spectrosc 11:193-199

Tallmark B (1980) Population dynamics of Nassarius reticulatus (Gastropoda, Prosobranchia) in Gullmar Fjord, Sweden. Mar Ecol Prog Ser 3:51-62

Tolosa I, Readman J, Blaevoet A, Ghilini S, Bartocci J, Horvat M (1996) Contamination of Mediterranean (Cote d'Azur) coastal waters by organotins and Irgarol 1051 used in antifouling paints. Mar Pollut Bull 32:335-341

Submitted: April 25, 2001; Accepted: September 27, 2001

Proofs received from author(s): March 18, 2002 